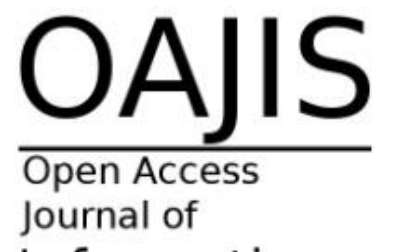

Information

Systems

is.its.ac.id/pubs/oajis/
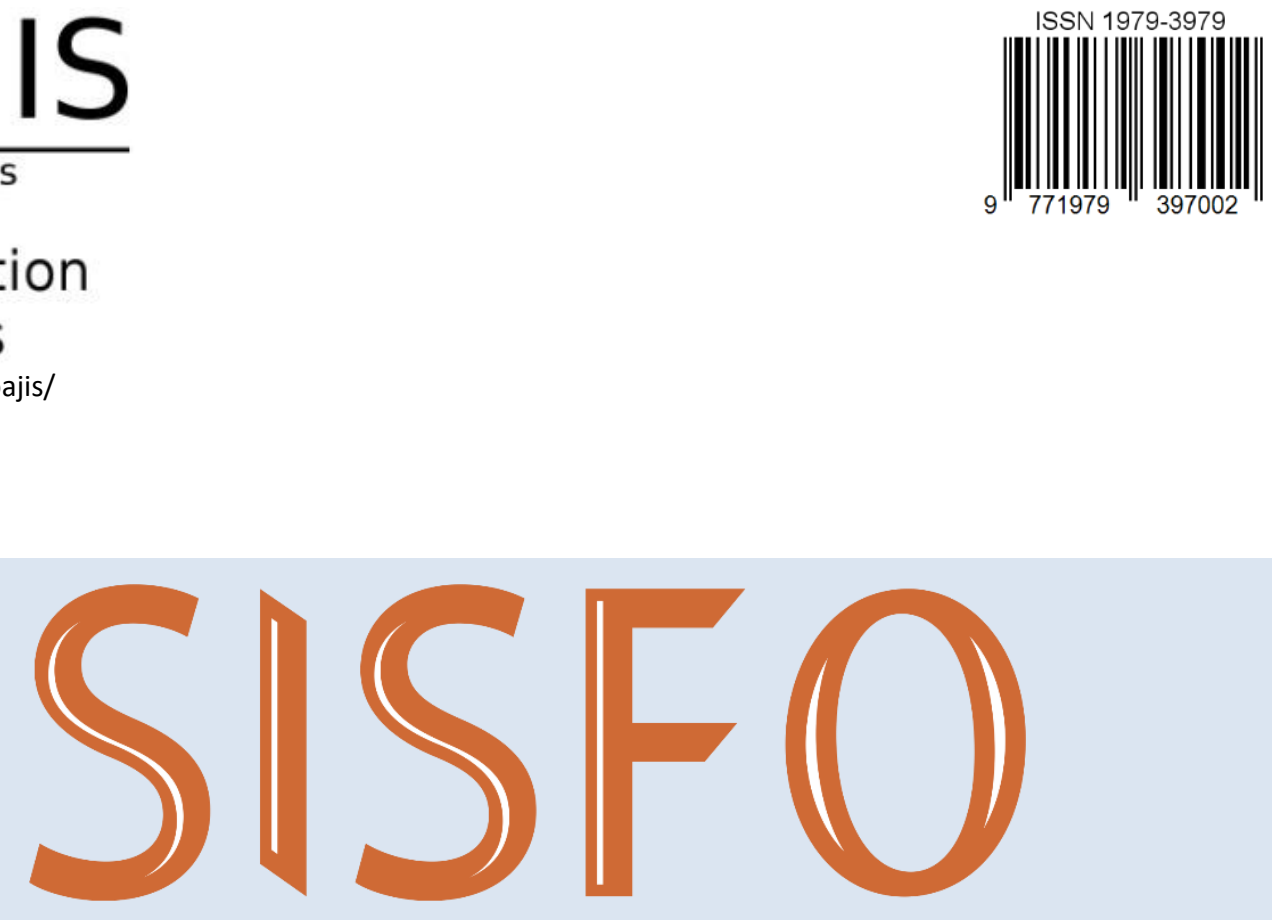

Inspirasi Profesional Sistem Informasi

\section{People}

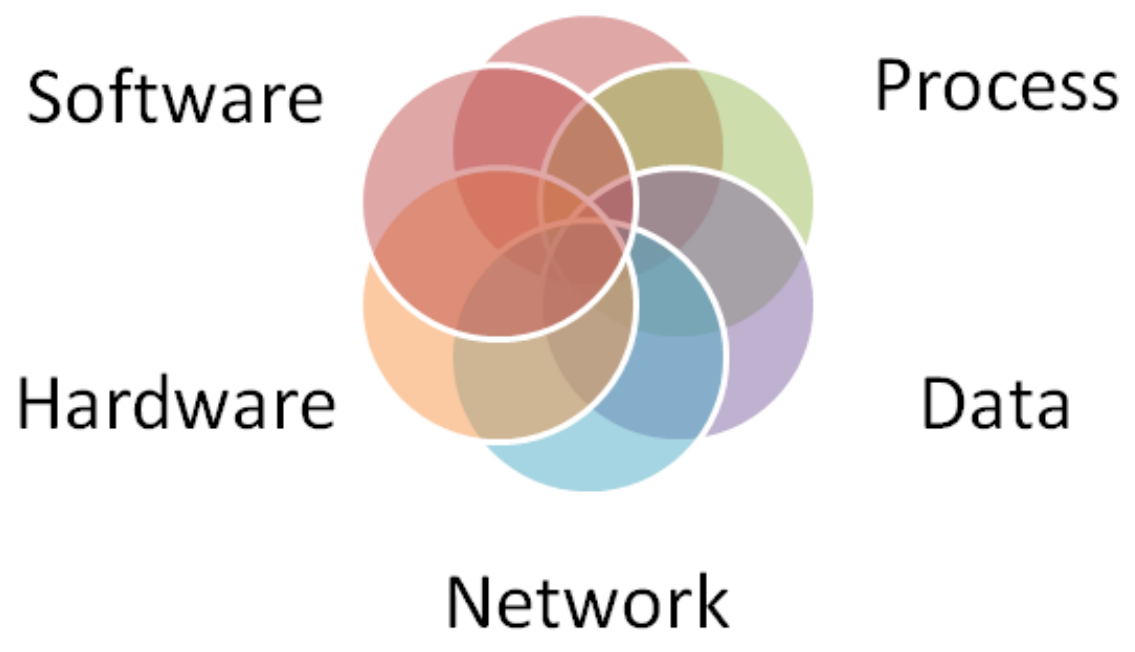


OAJIS

Journal of

Information

Systems

is.its.ac.id/pubs/oajis/

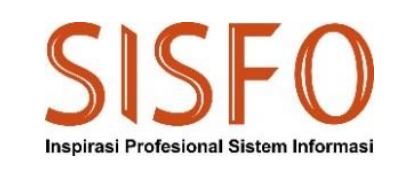

Jurnal Sisfo Vol. 08 No. 03 (2019) i-ii

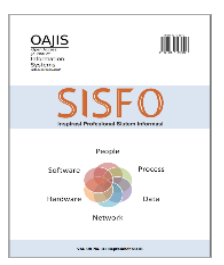

\section{Pimpinan Redaksi}

Faizal Mahananto

\section{Dewan Redaksi}

Eko Wahyu Tyas Darmaningrat

Amna Shifia Nisafani

Arif Wibisono

Rully Agus Hendrawan

\section{Tata Pelaksana Usaha}

\section{Achmad Syaiful Susanto}

Rini Ekowati

\section{Sekretariat}

Departemen Sistem Informasi - Fakultas Teknologi Informasi dan Komunikasi

Institut Teknologi Sepuluh Nopember (ITS) - Surabaya

Telp. 031-5999944 Fax. 031-5964965

Email: editor@jurnalsisfo.org

Website: http://jurnalsisfo.org

Jurnal SISFO juga dipublikasikan di Open Access Journal of Information Systems (OAJIS)

Website: http://is.its.ac.id/pubs/oajis/index.php 
OAJIS

Journal of

Information

Systems

is.its.ac.id/pubs/oajis/

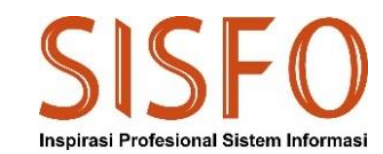

Jurnal Sisfo Vol. 08 No. 03 (2019) i-ii

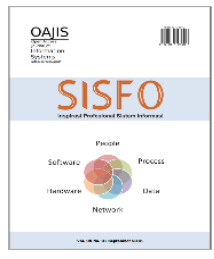

\section{Mitra Bestari}

Nur Aini Rakhmawati, Ph.D. (Institut Teknologi Sepuluh Nopember)

Rahadian Bisma, M.Kom. ITILF. (Universitas Negeri Surabaya)

Raras Tyasnurita, S.Kom, M.BA, Ph.D. (Institut Teknologi Sepuluh Nopember)

Satria Fadil Persada, S.Kom, M.BA, Ph.D (Institut Teknologi Sepuluh Nopember)

Sholiq, S.T, M.Kom, M.SA. (Institut Teknologi Sepuluh Nopember) 


\section{OAJIS \\ Open Access \\ Information \\ Systems \\ is.its.ac.id/pubs/oajis/}

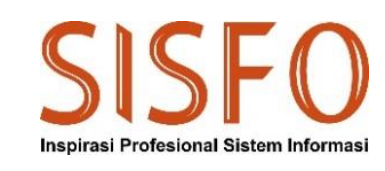

Jurnal Sisfo Vol. 08 No. 03 (2019) iii

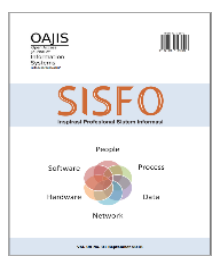

\section{Daftar Isi}

Identifikasi Karakteristik Teknik Elisitasi pada Rekayasa Kebutuhan Perangkat Lunak: Sebuah Review Sistematis

Endang Sulistiyani, Sasmi Hidayatul Yulianingtyas

Model Sistem Teleradiologi untuk Akses Pelayanan Kesehatan Rujukan

Romeo, Agus Sujadi

Integrasi Algoritma Blowfish untuk Pengamanan Data pada File MP3 dengan Steganografi LSB

Bonifacius Vicky Indriyono

Penyusunan Panduan Perawatan Software dan Hardware Pemerintah Kota Madiun Berdasarkan ISO/IEC 14764:2006 dan ITIL V3 2011

Umi Ridhoi, Anisah Herdiyanti, Tony Dwi Susanto.

Pengaruh Teknologi Informasi dalam Pertukaran Informasi dan Integrasi Rantai Pasok terhadap Performa Rantai Pasok

Achmad Wildan Nabila, Mahendrawathi ER 206 
Halaman ini sengaja dikosongkan 


\title{
Identifikasi Karakteristik Teknik Elisitasi pada Rekayasa Kebutuhan Perangkat Lunak: Sebuah Review Sistematis
}

\author{
Endang Sulistiyani ${ }^{\mathrm{a}, *}$, Sasmi Hidayatul Yulianing Tyas ${ }^{\mathrm{b}}$ \\ ${ }^{a}$ Departemen Sistem Informasi, Fakultas Teknik, Universitas Nahdlatul Ulama Surabaya \\ ${ }^{b}$ Departemen Sistem Informasi, Fakultas Teknologi Informasi dan Komunikasi, Institut Teknologi Sepuluh Nopember
}

\begin{abstract}
Accuracy of elicitation techniques selection will affect the quality of software requirements. However, mostly the selection was based on familiarity only. Therefore, it is necessary to identify the characteristics of each technique and its development. The identification was initialized through paper review on requirements elicitation topics published between 2001-2016. The results show that interviews are most frequently studied techniques. In addition, interviews, brainstorming, and document analysis considered as developed techniques. The developments are related to the use of processing tools from interviews such as tool ladder, electronic communication software and analytical techniques, namely social network analysis and collaborative filtering. The use of web application tools and social network sites marked the development of brainstorming technique. While in document analysis, the involvement of business process models and organizational models characterized the development. Interviews, brainstorming, and document analysis are most frequently used combinations techniques. Document analysis is used to find basic information, while interview is used to engaged with core users, and brainstorming is used to determine the list of requirements.
\end{abstract}

Keywords: Characteristic, Elicitation Technique, Requirement Elicitation, Software Development

\begin{abstract}
Abstrak
Ketepatan pemilihan teknik elisitasi akan berpengaruh pada kualitas kebutuhan perangkat lunak. Namun, seringkali pemilihannya hanya dilakukan berdasarkan familiaritas. Oleh karena itu, perlu adanya identifikasi karakteristik teknik dan perkembangannya. Identifikasi diinisialisasi melalui review paper dari tahun 2001-2016 dengan topik elisitasi kebutuhan. Hasilnya menunjukkan bahwa interview adalah teknik yang paling sering diteliti. Interview, brainstorming, dan analisa dokumen adalah teknik yang mengalami perkembangan. Pada interview, perkembangan ditunjukkan dengan penggunaan software tool ladder, electronic communication dan teknik analisis seperti social network analysis dan collaborative filtering. Pada brainstorming, perkembangan ditunjukkan dengan penggunaan fasilitas web application tools dan social network site, sedangkan pada analisa dokumen ditunjukkan dengan pelibatan model proses bisnis dan model organisasi. Interview, brainstorming, dan analisa dokumen merupakan komposisi kombinasi teknik elisitasi yang paling sering digunakan. Analisa dokumen digunakan untuk menemukan informasi dasar, interview untuk memperdalam dengan pengguna inti, dan brainstorming untuk menentukan daftar kebutuhan.
\end{abstract}

Kata kunci: Karakteristik, Teknik Elisitasi, Requirement Elicitation, Pengembangan Perangkat Lunak

(C) 2019 Jurnal SISFO.

Histori Artikel: Disubmit 12-02-2019; Direvisi 25-03-2019; Diterima 28-04-2019; Tersedia online 03-05-2019

*Corresponding Author

Email address: sulistiyani.endang @unusa.ac.id (Endang Sulistiyani)

https://doi.org/10.24089/j.sisfo.2019.05.001 


\section{Pendahuluan}

Rekayasan kebutuhan menjadi salah satu tantangan utama dalam life cycle pengembangan perangkat lunak. Berkualitas tidaknya kebutuhan yang berhasil diidentifikasi berpengaruh pada kesuksesan perangkat lunak yang dihasilkan [1] . Berkenaan dengan hal tersebut, proses yang bertujuan untuk mengidentifikasi kebutuhan perangkat lunak sebagai alternatif solusi dari permasalahan organisasi dan domain aplikasi adalah elisitasi kebutuhan. Aktivitas ini memiliki pengaruh yang cukup besar, sebagaimana disebutkan oleh Mohd Kasirun [2] bahwa kesuksesan aktivitas elisitasi kebutuhan memberi dampak yang besar pada ketercapaian tujuan rekayasa kebutuhan, dimana akan memastikan pengembangan aplikasi yang tepat.

Elisitasi kebutuhan perangkat lunak yang buruk merupakan bagian penting dan menjadi penyebab utama potensi kegagalan pembangunan sistem perangkat lunak. Hal ini didukung oleh laporan Standish yang menyatakan bahwa lebih dari setengah kegagalan pembangunan sistem terjadi karena elisitasi kebutuhan yang buruk [3-5]. Selain itu, Lamsweerde [5], Boehm [6] dan Molokken [7] juga melakukan penelitian yang sama dengan membuat pengukuran efek dari elisitasi kebutuhan yang buruk. Berdasarkan beberapa penelitian tersebut dihasilkan bahwa dalam rentang antara $12 \%$ sampai $71 \%$ kegagalan disebabkan oleh buruknya elisitasi kebutuhan. Terdapat juga penelitian yang secara akurat menghasilkan bahwa kebutuhan sistem adalah faktor utama kegagalan pada $91 \%$ proyek perangkat lunak yang berskala besar [8].

Saat ini, cukup banyak teknik elisitasi kebutuhan yang sudah dikembangkan. Sebagaimana diketahui, bahwa terdapat 9 teknik elisitasi, yakni interview dan kuesioner, wokshop, brainstorming, storyboard, use case, role playing, prototyping, analisa dokumen, dan Joint Application Design (JAD) [9]. Akan tetapi pada praktiknya, ketika analis sistem akan menentukan kebutuhan perangkat lunak, seringkali hanya satu teknik yang biasa dipakai, yakni interview. Hal ini dikarenakan belum disadarinya manfaat masing-masing teknik dan tersedianya panduan dalam pemilihan teknik, pengembang hanya mengedepankan kemudahan dan familiaritas, bukan pada feature dan strength [10]. Lebih lanjut, disebutkan oleh Hickey [11], bahwa seringkali teknik elisitasi dipilih hanya karena teknik tersebut yang diketahui, teknik tersebut pernah efektif digunakan pada waktu yang lalu sehingga diasumsikan akan efektif juga digunakan saat ini.

Padahal Beyer [10] dalam penelitiannya telah menemukan bukti bahwa interview tidaklah cukup untuk menggali kebutuhan dalam pengembangan perangkat lunak saat ini. Penulis lain Maiden dan Rugg menambahkan bahwa dimungkinkan penggunaan lebih dari satu teknik elisitasi untuk perangkat lunak yang semakin kompleks [10]. Terlebih, kebanyakan teknik elisitasi kebutuhan yang saat ini ada memiliki kekurangan dalam mengumpulkan kebutuhan dengan natural flow [12]. Di sisi lain, manusia secara alami lebih nyaman berkomunikasi dan berbagi informasi dengan bahasa keseharian yang digunakan. Isu lain yang berkembang adalah, proyek perangkat lunak yang dikembangkan tidak selalu memiliki karakteristik yang sama. Selain itu, sebagaimana disebutkan beberapa penulis terkait permasalahan dalam elisitasi kebutuhan adalah semakin luas skala dari proyek. Bagaimana pun juga, secara alamiah satu teknik elisitasi tidak dapat digunakan pada semua situasi. Sama halnya dengan proyek, ketepatan penggunakan teknik juga berbeda- beda [9].

Oleh karena itu, muncullah ide untuk mengidentifikasi karakteristik masing-masing teknik yang ada. Karakteristik ini meliputi kelebihan, kekurangan, pengimplementasiannya, serta perkembangannya. Sehingga dapat membantu analis sistem dalam memilih teknik elistasi yang tepat. Harapannya aktivitas elisitasi kebutuhan akan menjadi lebih efektif dan dapat menghasilkan kebutuhan yang berkualitas.

Adapun pertanyaan penelitian pada review ini adalah sebagai berikut:

1) Bagaimana karakteristik dari masing-masing teknik elisitasi?

2) Bagaimana perkembangan implementasi teknik elisitasi? 


\section{Tinjauan Pustaka/Penelitian Sebelumnya}

\subsection{Definisi Elisitasi Kebutuhan}

Tahapan pertama dalam rekayasa kebutuhan perangkat lunak adalah proses elisitasi kebutuhan. Pemahaman terhadap permasalahan dan domain aplikasi merupakan definisi dari aktivitas ini. Proses ini merupakan sekumpulan aktivitas yang ditujukan untuk menemukan kebutuhan suatu system melalui komunikasi dengan pelanggan, pengguna system, dan pihak lain yang memiliki kepentingan dalam pengembangan system [9]. Luarannya berupa daftar kebutuhan yang akn dituliskan dalam dokumen kebutuhan pengguna [2].

\subsection{Teknik Elisitasi}

Kebutuhan dapat dihasilkan dalam proses elisitasi kebutuhan dengan bantuan berbagai teknik. Saat ini sudah dikenal beberapa teknik elisitasi yang berkembang, meliputi: interview, kuesioner, requirement workshop, brainstorming, storyboard, use cases, role playing, protoyping, Joint Application Design (JAD), dan analisa dokumen [9]. Definisi masing-masing teknik dijelaskan pada ulasan berikut ini:

\section{1) Interview}

Metode untuk mengidentifikasi fakta dan opini tentang apa yang dilakukan stakeholder dan bagaimana mereka melakukan hal tersebut. Metode ini dilakukan dengan cara bertanya. Tantangan dalam penggunaan teknik ini adalah perlunya pemahaman yang mendalam terkait hal yang akan ditanyakan untuk interviewer dan kepandaian dalam menjelaskan pengetahuan yang dimiliki bagi ahli yang menjadi narasumber

2) Kuesioner

Teknik elisitasi yang membantu mendapatkan informasi dari banyak orang. Kesuksesan penggunaa teknik ini tergantung pada desain kuesioner dan bagaimana pengarah sesi pengisian kuesioner memandu.

3) Requirement workshop salah satu teknik elisitasi kebutuhan dimana teknik ini mempertemukan tim developer dan stakeholder proyek untuk mengumpulkan dan mendefinisikan kebutuhan-kebutuhan proyek dalam bentuk workshop.

4) Brainstorming

Teknik yang menyediakan lingkungan diskusi yang bebas, dimana seluruh user dibebaskan untuk berfikir dan mengumpulkan ide. Selajutnya dilakukan proses reduksi untuk mengeliminasi ide yang kurang sesuai berdasarkan hasil pemeringkatan.

5) Storyboard

Teknik yang berupa serangkaian ilustrasi atau gambar yang ditampilkan secara berurutan untuk tujuan memvisualisasikan kebutuhan. Visualisasi ini bertujuan utuk menjelaskan rincian antarmuka antara manusia dengan sistem.

6) Use cases

Teknik elisitasi berdasarkan skenario yang menjelaskan interaksi antara aktor dengan sistem yang akan dibangun. Teknik ini berupa diagram fungsionalitas dari suatu sistem, sehingga pengguna sistem paham dan mengerti mengenai kegunaan sistem yang akan dibangun.

7) Role playing

Teknik ini memberi kesempatan kepada stakeholder untuk bisa mengalami experience yamg sama dari sudut pandang user sebagai pengguna. Role playing menggunakan skenario yang diatur oleh tim developer, dengan dialog yang spontan.

8) Prototyping 
Teknik ini merupakan versi awal dari sistem perangkat lunak yang digunakan untuk mendemonstrasikan konsep, mencoba pilihan rancangan, dan secara umum mencari lebih jauh tentang kesalahan dan solusi yang dimungkinkan.

9) Joint Aplication Design (JAD)

Teknik dalam mengumpulkan kebutuhan suatu sistem dimana dalam proses pengumpulannya melibatkan pihak buyer (key users) untuk berpartisipasi aktif dan bekerja sama dalam mengumpulkan kebutuhan-kebutuhan tersebut dengan pihak developer (IT specialists/systems professionals).

10) Analisa dokumen

Teknik pengumpulan kebutuhan dengan cara menganalisa dokumen yang terkait dengan domain permasalahan dalam organisasi.

\subsection{Peranan Teknik Elisitasi Kebutuhan dalam Rekayasa Kebutuhan Perangkat Lunak}

Pengaruh yang besar diberikan oleh kesuksesan proses elisitasi kebutuhan terhadap pencapaian tujuan rekayasa kebutuhan. Kualitas kebutuhan yang dihasilkan akan berpengaruh pada proses selanjutnya hingga ketepatan aplikasi yang dikembangkan [2]. Sukses atau gagalnya pengembangan perangkat lunak dipengaruhi oleh kualitas kebutuhan. Hal ini berarti bahwa elisitasi kebutuhan yang merupakan penginisiasi kebutuhan harus dilakukan dengan benar agar menghasilkan kebutuhan yang berkualitas [1]. Ketepatan proses elisitasi kebutuhan dipengaruhi oleh ketepatan pemilihan teknik elistasi. Sebagaimana disebutkan oleh beberapa penulis bahwa dimungkinkan penggunaan berbagai teknik elisitasi untuk mendapatkan kebutuhan pada sebuah sistem.

\subsection{Penelitian Sebelumnya}

Beberapa penelitian yang sudah ada sebelumnya dan menjadi acuan untuk gagasan ini disajikan dalam Tabel 1.

Tabel 1. Penelitian sebelumnya

\begin{tabular}{|c|c|c|}
\hline No & Judul & Hasil \\
\hline \multirow[t]{3}{*}{1.} & \multirow{3}{*}{$\begin{array}{l}\text { Systematic Review of } \\
\text { Requirement Elicitation } \\
\text { Techniques[13] }\end{array}$} & $\begin{array}{l}\text { 1) Teknik elistasi kebutuhan adalah hal yang penting karena menghasilkan kebutuhan yang } \\
\text { menjadi kunci kesuksesan pengembangan perangkat lunak. }\end{array}$ \\
\hline & & 2) Tidak ada satu teknik yang dapat memenuhi keseluruhan elisitasi kebutuhan. \\
\hline & & $\begin{array}{l}\text { 3) Akan tetapi yang perlu diingat adalah kesuksesan elisitasi kebutuhan bukan tergantung } \\
\text { jumlah teknik yang digunakan tetapi ketepatan memilih teknik }\end{array}$ \\
\hline \multirow[t]{3}{*}{2.} & \multirow{3}{*}{$\begin{array}{l}\text { Selecting Requirement } \\
\text { Elicitation Techniques for } \\
\text { Software Project [9] }\end{array}$} & $\begin{array}{l}\text { 1) Masing-masing teknik memiliki karakteristik yang berbeda. Begitu halnya dengan proyek, } \\
\text { juga memiliki karakterisik yang berbeda. }\end{array}$ \\
\hline & & $\begin{array}{l}\text { 2) Ketika memilih teknik elisitasi untuk menghasilkan kebutuhan pada proyek tertentu perlu } \\
\text { disesuaikan dengan karakteristiknya. }\end{array}$ \\
\hline & & $\begin{array}{l}\text { 3) Framework yang dihasilkan berupa uraian langkah untuk memilih melalui hasil identifikasi } \\
\text { karakteristik, sehingga sangat tergantung pada kemampuan analis sistem. Perlu adanya } \\
\text { pemetaan fungsi agar memberi informasi secara visual yang lebih baik. }\end{array}$ \\
\hline \multirow[t]{4}{*}{3} & \multirow{4}{*}{$\begin{array}{l}\text { Elicitation Technique } \\
\text { Selection: How Do Experts } \\
\text { Do it? [11] }\end{array}$} & Sering kali analis kebutuhan memilih teknik elisitasi berdasarkan beberapa asumsi berikut ini: \\
\hline & & 1) Teknik yang dipilih adalah satu-satunya teknik yang diketahui \\
\hline & & $\begin{array}{l}\text { 2) Karena teknik yang dipilih pernah bekerja secara efektif sebelmnya, maka menurutnya juga } \\
\text { akan sama }\end{array}$ \\
\hline & & $\begin{array}{l}\text { 3) Analis sistem mengikuti metodologi yang pernah ada dan serta merta menggunakan pada } \\
\text { waktu sekarang. }\end{array}$ \\
\hline
\end{tabular}


Berdasarkan beberapa penelitian sebelumnya diperoleh informasi bahwa ketepatan pemilihan teknik elisitasi menjadi tantangan tersendiri, karena menghasilkan kebutuhan yang menjadi kunci kesuksesan pengembangan perangkat lunak. Akan tetapi yang perlu diperhatikan adalalah tidak ada satu pun teknik yang cocok untuk semua situasi. Sementara itu, sering kali analis kebutuhan memilih teknik bukan karena fitur dan kekuatannya melainkan berdasarkan familiaritas teknik. Saat ini sudah ada framework untuk memilih teknik elisitasi, akan tetapi masih belum eksplisit memberikan panduan. Analis sistem masih harus mengidentifikasi karakteristik domain kebutuhan dan sistem untuk dapat menentukan teknik yang tepat. Kondisi ini masih rentan dengan kekeliruan tergantung kedalaman analisa. Oleh karena perlu kiranya identifikasi yang lebih mendalam terhadap karakteristik masing-masing teknik dan perkembangannya. Hal ini diharapkan dapat membantu menghasilkan kebutuhan yang lebih berkualitas dan nantinya akan menjadi masukan dalam pemetaan teknik elisitasi dengan karakteristik perangkat lunak.

\section{Metodologi}

Pada bagian ini akan dijelaskan tentang hal-hal yang dilakukan dalam penelitian ini. Paper ini merupakan jenis paper summarize yang dihasilkan dari penggabungan hasil beberapa paper lainnya. Metode penelitian dan penyusunan paper ini terutama berfokus pada metode pengumpulan paper. Langkah-langkah yang dilakukan dalam penelitian ini adalah mencari paper, memilih paper, review paper, dan identifikasi karakteristik teknik elisitasi. Alur metodologi penelitian diperlihatkan pada Gambar 1.

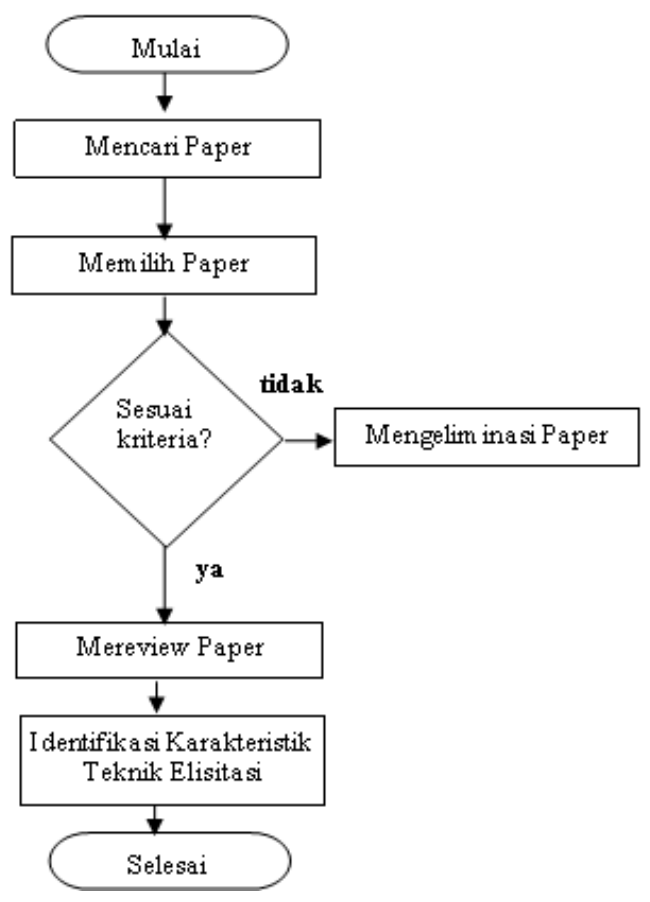

Gambar 1. Alur metodologi penelitian

\subsection{Mencari Paper}

Pencarian paper dilakukan pada berbagai sumber yaitu IEEE, Science Direct, Google Scholar, dan Springer. Beberapa kata kunci yang digunakan untuk mencari paper pada masing-masing sumber adalah requirement elicitation, requirement elicitation technique, dan software requirement elicitation technique. Kemudian dilakukan pengaturan terhadap rentang tahun dari paper dan hanya menjaring paper atau jurnal dan prosiding. Dalam hal ini digunakan paper yang diterbitkan antara tahun 2000 sampai dengan 2016. 
Pencarian paper juga berdasarkan masing-masing teknik elisitasi dengan menggunakan nama teknik elisitasi sebagai kata kunci pencarian. Jenis-jenis teknik elisitasi yang diteliti adalah interview dan kuesioner, workshop, brainstorming, Joint Application Design (JAD), storyboard, usecase, role playing, prototyping dan analisa dokumen. Pencarian paper menghasilkan 50 paper yang berhasil diunduh dan sesuai dengan kata kunci serta tahun diterbitkan. Hal ini karena tidak semua paper dapat diunduh dan ada beberapa yang harus membeli. Pencarian ini dilakukan kurang lebih selama 2 minggu, dimana setiap harinya minimal 3 paper.

\subsection{Memilih Paper}

Paper yang dihasilkan dari tahap pencarian kemudian dipilih yang sesuai. Pemilihan paper dilakukan dengan kriteria inklusi dan eksklusi. Untuk kriteria inklusi adalah sebagai berikut:

1) Paper mengulas minimal salah satu dari 9 teknik elisitasi yang ditentukan

2) Paper yang diterbitkan pada rentang tahun 2000 sampai 2016

3) Ulasan paper meliputi karakteristik teknik elisitasi

Sedangkan kriteria eksklusi yang diterapkan adalah posisi teknik elisitasi dalam paper hanya sebagai alat bantu tanpa ada justifikasi penggunaannya. Setelah dilakukan pemilihan dengan kriteria tersebut, maka dihasilkan sebanyak 25 paper yang sesuai. Paper-paper yang tidak sesuai kriteria akan dieliminasi, yaitu sebanyak 25 paper.

\subsection{Review Paper}

Paper yang telah dipilih pada tahap sebelumnya, kemudian masing-masing dibaca dan dirangkum hasilnya. Hal yang menjadi pokok dalam merangkum paper-paper tersebut adalah permasalahan yang melatarbelakangi penelitian pada paper, jenis teknik elisitasi yang dibahas dalam paper, karakteristik teknik elisitasi, penerapan teknik elisitasi pada pengembangan perangkat lunak tertentu, perkembangan dari teknik tradisional, dan hasil dari perbandingan dengan teknik lain. Selanjutnya dari hasil dari paper review maka dibuat pengelompokan hasil review masing-masing paper berdasarkan 9 jenis teknik elisitasi dalam bentuk tabel. Hal ini dilakukan untuk memudahkan dalam proses identifikasi kelebihan, kekurangan dan perkembangan pada masing-masing teknik elisitasi serta mengetahui kombinasi antar beberapa teknik elisitasi.

\subsection{Identifikasi Karakteristik Teknik Elisitasi}

Tahap selanjutnya melakukan analisis terhadap hasil dari tahap review. Dari hasil review paper telah diketahui teknik apa saja yang digunakan pada teknik elisitasi dan karakteristik serta penerapannya pada masing-masing paper. Pada tahap analisis dilakukan identifikasikekurangan dan kelebihan dari masingmaisng teknik elisitasi. Selain itu juga dilakukan analisis perkembangan teknik elisitasi dari tahun ke tahun dari hasil pengelompokan teknik elisitasi berdasarkan tahun terbit paper. Hasil analisis tersebut kemudian disajikan dalam bentuk grafik atau diagram yang terdiri dari diagram persebaran teknik elisitasi pada setiap tahun, grafik perkembangan penelitian pada masing-masing teknik elisitasi dengan rentang tahun tertentu, diagram jumlah paper berdasarkan sumber, tabel kombinasi teknik elisitasi pada setiap paper dan diagram jumlah paper berdasarkan tahun terbit. Pada akhir tahap ini akan dihasilkan karakteristik dan beberapa grafik perkembangan dari masing-masing teknik elisitasi.

\section{Hasil dan Pembahasan}

Pada bagian ini dijelaskan tentang hasil dan pembahasan. Hasil merupakan rekapitulasi jumlah paper yang menjadi acuan apabila dikelompokkan berdasarkan tahun dan sumber, grafik perkembangan dan 
persebaran teknik elisitas pada setiap tahunnya. Pembahasan berisi tentang ulasan tentang karakteristik dari masing-masing teknik elisitasi dan perkembangan serta hasil analisis terhadap grafik yang dibahas pada bagian hasil.

\subsection{Hasil}

Hasil pengelompokan paper disajikan dalam bentuk grafik atau diagram yang terdiri dari diagram persebaran teknik elisitasi pada setiap tahun, grafik perkembangan penelitian pada masing-masing teknik elisitasi dengan rentang tahun tertentu, diagram jumlah paper berdasarkan sumber, tabel kombinasi teknik elisitasi pada setiap paper dan diagram jumlah paper berdasarkan tahun terbit.

Pada tahap pencarian paper ditemukan sebanyak 44 paper dari berbagai sumber yaitu 15 paper dari IEEE, 5 paper dari Science Direct, 26 paper dari Google Scholar, dan 2 paper dari Springer. Selain itu juga dilakukan pencarian terhadap paper yang menjadi rujukan dari 44 paper tersebut, sehingga dihasilkan paper tambahan sebanyak 6 paper. Sumber dari 6 paper tersebut adalah satu paper dari IEEE dan 5 paper dari Google Scholar. Jumlah keseluruhan paper adalah sebanyak 50 paper. Tahap pemilihan paper menghasilkan 25 paper yang sesuai kriteria dan 25 paper yang lainnya tidak sesuai. Dari 25 paper yang sesuai kriteria tersebut berasal dari IEEE sebanyak 11 paper, Science Direct 1 paper, Google Scholar 12 paper dan Springer 1 paper seperti ditunjukkan pada Gambar 2.

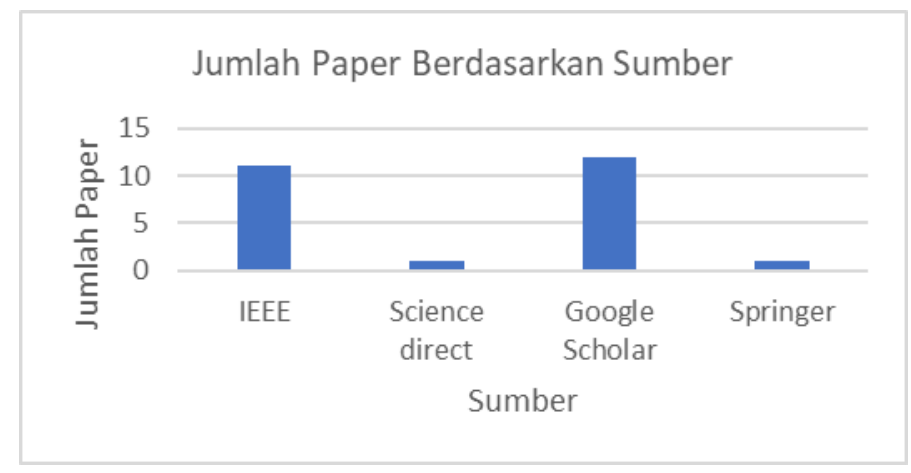

Gambar 2. Diagram jumlah paper berdasarkan sumber

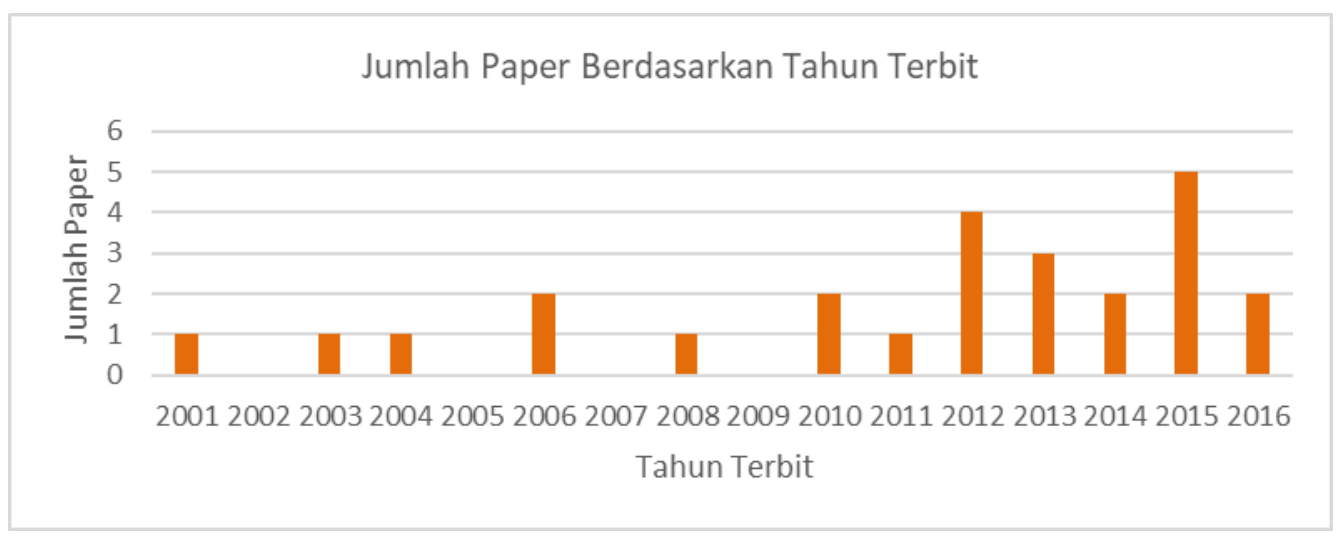

Gambar 3. Diagram jumlah paper berdasarkan tahun terbit

Pada Gambar 3 disajikan hasil rekapitulasi jumlah paper pada setiap tahunnya antara tahun 2001 sampai 2016. Tidak ada diantara 25 paper acuan yang diterbitkan pada tahun 2002, 2005, 2007, dan 2009. 
Terdapat 1 paper pada masing-masing tahun 2001, 2003, 2004, 2008 dan 2011. Sedangkan pada tahun 2006, 2010, 2014, dan 2016 masing-masing terdapat 2 paper. Tahun 2013 terdapat 3 paper dan 4 paper di tahun 2012 serta di tahun 2015 terdapat 5 paper.

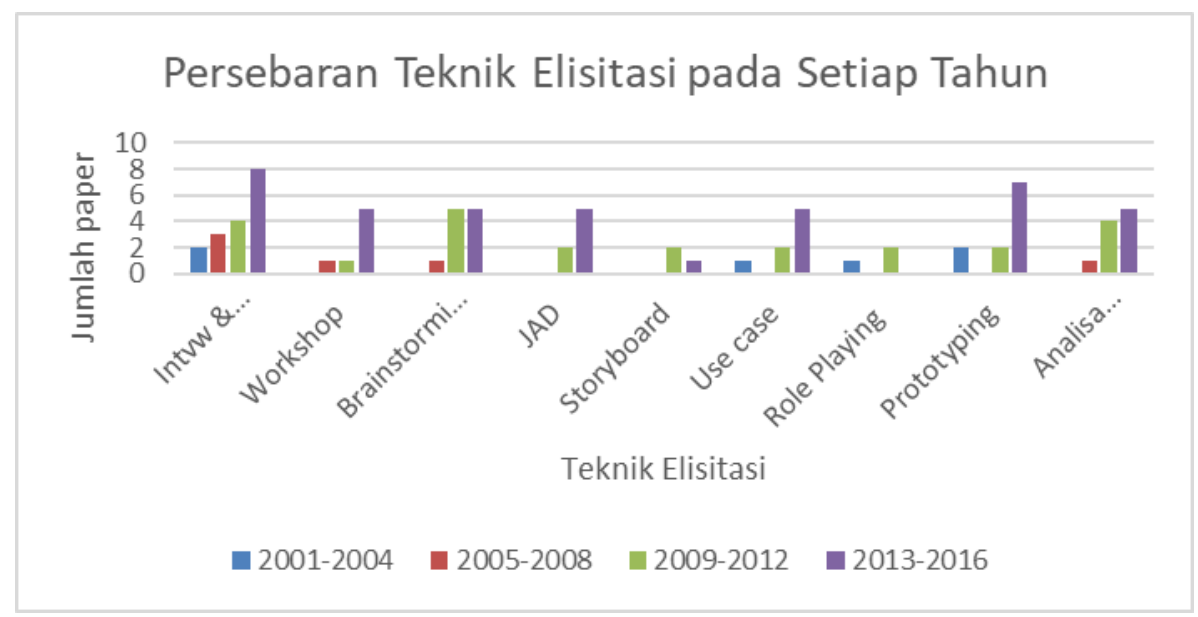

Gambar 4. Persebaran teknik elisitasi pada setiap tahun

Berdasarkan Gambar 4 ditunjukkan bahwa setiap teknik elisitasi diteliti pada rentang waktu tertentu. Rentang waktu dibagi menjadi 4 yaitu tahun 2001-2004, 2005-2008, 2009-2012 dan 2013-2016. Hal ini karena teknik elisitasi tidak diteliti di setiap tahunnya sehingga apabila dibuat per tahun akan banyak yang kosong. Pada Gambar 4 terlihat bahwa pada tahun 2001-2004 teknik elisitasi yang dibahas oleh paper hanya 6 yaitu interview dan kuesioner 2 paper, use case 1 paper, role playing 1 paper, prototyping 2 paper. Sedangkan pada tahun 2005-2008 terdapat 3paper membahas interview dan kuesioner, masing-masing 1 paper membahas workshop, brainstorming dan analisa dokumen.

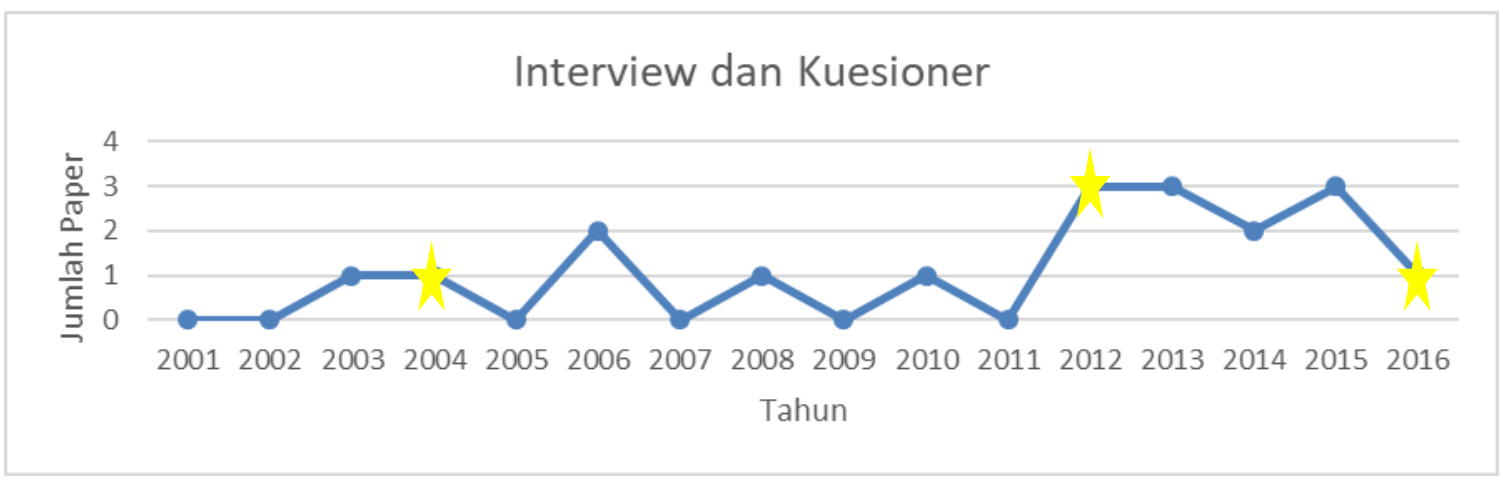

Gambar 5. Grafik perkembangan teknik interview dan kuesioner

Berdasarkan hasil review paper diketahui bahwa terdapat beberapa teknik elisitasi yang mengalami perkembangan dalam penerapannya yaitu teknik interview, brainstorming, dan analisa dokumen. Perkembangan dari masing-masing teknik elisitasi ditunjukkan oleh Gambar 5 sampai Gambar 7 ditandai dengan bintang berwarna kuning. Pada Gambar 5 ditunjukkan bahwa pengembangan teknik interview dan kuesioner terjadi pada tahun 2004, 2012, dan 2016. Meskipun pada tahun-tahun tersebut bukan merupakan tahun dengan jumlah paper yang paling banyak, karena jumlah paper tersebut merepresentasi jumlah paper yang mengulas teknik tersebut. Teknik interview tidak diulas pada semua tahun. Namun hanya diulas pada 
tahun 2003, 2004, 2008, 2010, dan 2016 (1 paper), 2006 (2 paper), 2012, 2013, 2015 (3 paper), dan 2014 (2 paper).

Sedangkan pada Gambar 6 terlihat bahwa terdapat 2 kali pengembangan teknik brainstorming yaitu pada tahun 2010 dan 2016. Pada tahun 2001 sampai dengan 2007 tidak ada paper yang meneliti teknik ini. Penelitian dimulai pada tahun 2008 sebanyak 1 paper, 2010 diteliti oleh 2 paper, 2011, 2012, 2014 dan 2015 masing-masing 1 paper dan 2013 sebanyak 2 paper.

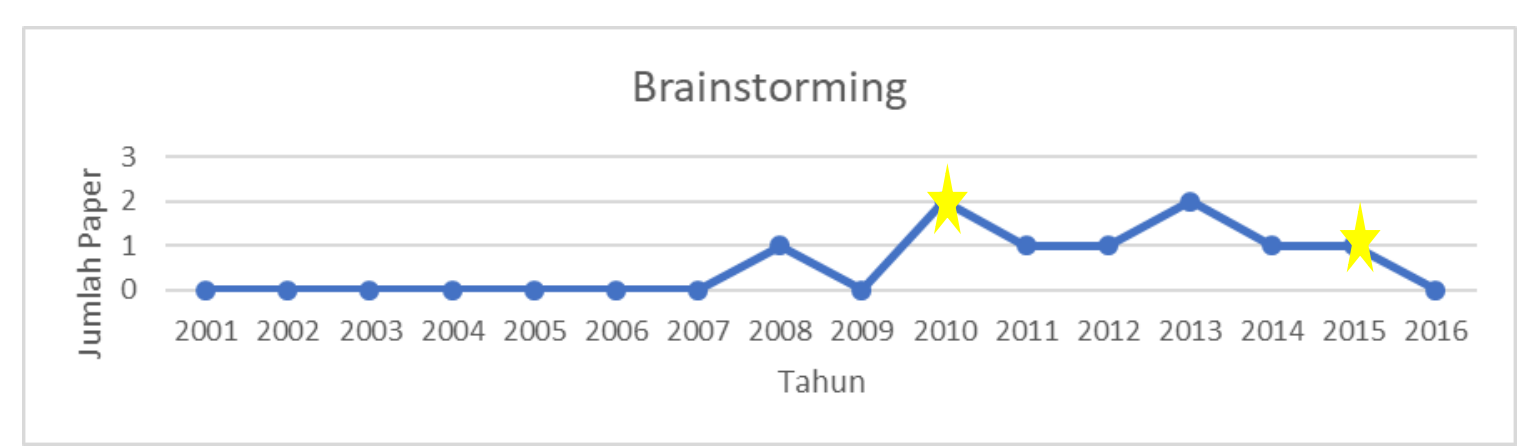

Gambar 6. Grafik perkembangan penelitian teknik brainstorming

Teknik analisa dokumen sepanjang tahun 2001 sampai dengan 2016 mengalami 2 kali pengembangan yaitu tahun 2012 dan 2013. Pada Gambar 7 ditunjukkan bahwa peneltian tentang analisa dokumen dimulai pada tahun 2006 sebanyak 1 paper, kemudian hingga tahun 2010 baru ada yang meneliti kembali sebanyak 1 paper. Puncaknya ada pada tahun 2012 dan 2013 yang sama-sama diteliti pada 3 paper. Pada tahun berikutnya jumlahnya menurun menjadi 2 paper di masing-masing tahun 2014 dan 2015. Sedangkan tahun 2016 tidak ada paper yang mengulas tentang teknik analisa dokumen.

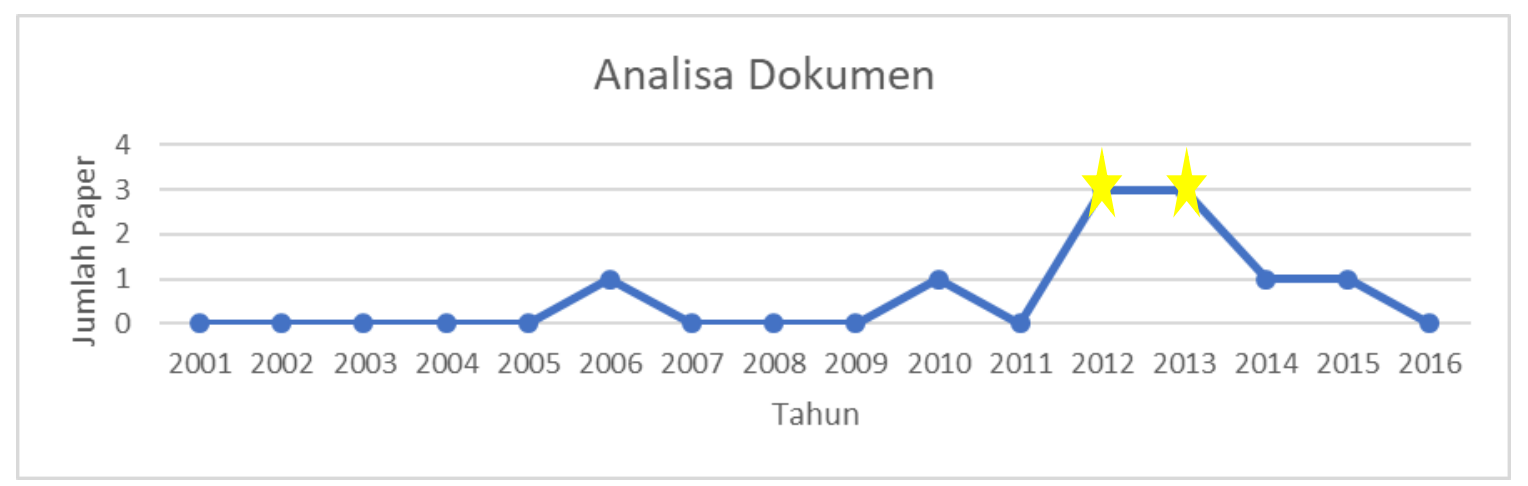

Gambar 7. Grafik perkembangan teknik analisa dokumen

\subsection{Pembahasan}

Bagian ini berisi uraian tentang karakteristik dan perkembangan dari masing-masing teknik elisitasi yang dihasilkan dari tahap review paper. Teknik-teknik elisitasi yang akan diuraikan adalah interview dan kuesioner, workshop, brainstorming, Joint Application Design (JAD), storyboard, usecase, role playing, prototyping, dan analisa dokumen. 


\subsubsection{Interview dan Quesioner}

Interview merupakan teknik penggalian kebutuhan yang dilakukan oleh interviewer dengan mengajukan pertanyaan kepada narasumber [9][11]. Teknik ini cocok untuk mendapatkan latar belakang dan menginisiasi kebutuhan ketika pengerjaan sistem baru pada domain yang baru pula [9][11][14]. Saat ini, interview masih menjadi teknik yang paling banyak dan umum digunakan. Bentuk teknik ini bisa terstruktur atau tidak terstruktur [15][16][17][8]. Adanya interaksi secara personal dengan narasumber yang potensial, membuat teknik ini dapat menghasilkan informasi yang detail terkait kebutuhan karena interviewer dapat langsung menanggapi jika ada hal yang belum jelas [18][19][20][9].

Akan tetapi, penggalian kebutuhan menggunakan teknik ini membutuhkan waktu yang cukup lama dan mungkin tidak cukup hanya sekali dilakukan. Hal ini dikarenakan analis harus bekerja dua kali untuk merapikan kembali informasi yang diperoleh. Teknik ini juga tidak memungkinkan untuk sesi secara berkelompok [9]. Ketergantungan pada kualitas interaksi interviewer dan narasumber cukup besar. ketepatan pertanyaan, orang yang ditanya, dan bagaimana jawabannya adalah hal yang krusial pada penggunaan teknik ini [16][18][8][20].

Tantangan yang seringkali muncul dalam penggunaan teknik ini adalah interviewer harus memiliki pemahaman yang mendalam terkait hal yang akan ditanyakan dan bagaimana mengarahkan pertanyaan untuk mendapatkan informasi. Sementara itu, kedalaman dan kepandaian dalam menjelaskan pengetahuan yang dimiliki bagi ahli yang menjadi narasumber juga perlu diperhatikan ketika memilih narasumber.

Di sisi lain, teknik yang secara teori memiliki peran sebagai pelengkap teknik interview adalah kuesioner. Teknik ini berbanding terbalik dengan interview, dimana dapat mengumpulkan informasi dari kelompok stakeholder secara cepat [15][16][9]. Selain itu, kuesioner juga dapat menghasilkan data statistik, ide, dan saran yang memudahkan analisis [13].

Tantangannya adalah diperlukan keterampilan dalam mendesain kuesioner yang baik (mudah dipahami dan tidak menimbulkan persepsi ganda) [9][8]. Jumlah sampel juga harus ditentukan, follow up dan klarifikasi jawaban dari user tidak mudah dilakukan [15][21]. Oleh karena itu, pada praktiknya pengunaan kuesioner perlu dikombinasikan dengan teknik lain untuk mendetailkan data yang sudah diperoleh.

\subsubsection{Workshop}

Salah satu teknik elisitasi kebutuhan dimana teknik ini mempertemukan tim developer dan stakeholder proyek untuk mengumpulkan dan mendefinisikan kebutuhan proyek yang kompleks dan besar dalam bentuk workshop [15][19][9]. Setiap kelompok stakeholder mengirimkan perwakilan kuncinya untuk berkomunikasi dengan developer [9]. Interaksi developer dengan semua lapisan stakeholder akan lebih meningkat dengan cara komunikasi yang natural [9][14]. Hasilnya kebutuhan yang diperoleh lengkap, benar, konsisten, dan terdokumentasi dengan baik [22].

Akan tetapi karena teknik ini melibatkan partisipasi banyak pihak maka dibutuhkan usaha yang besar untuk mengumpulkan semua stakeholder [15]. Hal ini dikarenakan perlu adanya identifikasi ketersediaan waktu partisipan untuk menetapkan jadwal workshop. Perencanaan, jumlah, dan komposisi akan mempengaruhi hasil penggalian kebutuhan sehingga harus ditentukan dengan tepat [21]. Proses elisitasi juga cukup lambat karena harus melewati beberapa sesi [15]. Teknik ini bagus untuk meningkatkan komunikasi antara pengembang dan stakeholder, akan tetapi perlu menyesuaikan waktu banyak pihak yang akan mengikuti workshop. 


\subsubsection{Brainstorming}

Teknik yang menyediakan lingkungan diskusi yang bebas, dimana seluruh user dibebaskan untuk berfikir dan mengumpulkan ide [9]. Bagusnya teknik ini, pengumpulan ide tanpa dikritisi dulu sehingga tidak menurunkan semangat user [9]. Selanjutnya dilakukan proses reduksi untuk mengeliminasi ide yang kurang sesuai berdasarkan hasil prioritisasi [9]. Mengingat sifat alamiah sebuah teknik yang tidak menyelesaikan semua permasalahan, teknik ini juga sangat membantu dalam memilih requirement setelah dilakukan interview. Hasil interview yang berupa informasi belum terstrukur menjadi daftar kebutuhan melalui bantuan teknik ini [17]. Terkait karakteristik proyek yang cocok dengan teknik ini adalah proyek yang baru dan inovatif. Hal ini akan meningkatkan keterlibatan user dalam menggali ide dan menghasilkan kebutuhan dalam waktu singkat dengan berfokus pada permasalahan yang spesifik [23][15].

Akan tetapi teknik ini kurang efektif untuk permasalahan yang besar dan lebar [15]. Meskipun brainstorming sudah diarahkan untuk permasalahan yang spesifik, kebebasan berfikir yang diberikan teknik ini dapat mengakibatkan overload ide jika partisipan sangat aktif atau sebaliknya (minim ide) jika keaktifan peserta kurang. Sebagai teknik yang menggunakan interaksi secara natural, brainstorming dirasa kurang kuat dibandingkan dengan storyteling. Hal ini dikarenakan diskusi yang dilakukan belum dilengkapi dengan naluri alamiah manusia yang suka mengungkapkan ide melalui cerita [12].

\subsubsection{Joint Application Design (JAD)}

Teknik penumpulan kebutuhan suatu sistem dimana dalam prosesnya melibatkan pihak buyer (key users) untuk berpartisipasi aktif dan bekerja sama dalam mengumpulkan kebutuhan-kebutuhan tersebut dengan pihak developer (IT specialists/ systems professionals). Teknik ini meningkatkan komunikasi antara pihak developer dengan client sehingga menghasilkan pembelajaran yang berharga [18][20]. Client yang tidak paham aspek teknis akan mendapat penjelasan dari developer, sedangkan pihak spesialisasi TI akan belajar tentang permasalahan bisnis dari petinggi organisasi[9][18][20]. Menggunakan teknik ini, keputusan penyelesaian masalah dapat dibuat dengan cepat karena tujuan telah didefinisikan sebelum diskusi. Hal ini yang membedakan dengan teknik brainstorming[15]. Fokus pelaksanaannya adalah kebutuhan bisnis dan keinginan user dengan membawa semua stakeholder dalam satu pemahaman [15]. Kebutuhan dari pihak yang tidak ahli juga ditampung pada teknik ini. Penekanan keterlibatan stakeholder dapat menciptakan rasa kepemilikan proyek sehingga teknik ini cocok untuk pengembangan sitem yang membutuhkan waktu cepat dan kompleks [24].

Meskipun keterlibatan stakeholder penting, namun penekanan ini dapat menimbulkan pemasalahan karena tidak semua orang dapat mengungkapkan kebutuhannya di depan banyak orang [14]. Komitmen waktu sepenuhnya dari stakeholder menjadi hal yang krusial. Persiapan yang tidak matang dan dokumentasi yang tidak lengkap untuk sesi JAD akan membuat waktu terbuang sia-sia. Tidak hanya itu, permasalahan bahasa seringkali menjadi kendala pada pelaksanaannya, mengingat partisipan yang terlibat beranekaragam tingkat pendidikan dan keahlian. Akhir- akhir ini menjadi teknis elisitasi yang cukup popular dan menghasilkan lebih banyak kebutuhan [14].

\subsubsection{Storyboard}

Teknik yang berupa serangkaian ilustrasi atau gambar yang ditampilkan secara berurutan untuk tujuan memvisualisasikan kebutuhan. Visualisasi ini bertujuan utuk menjelaskan rincian antarmuka antara manusia dengan sistem. Penggunaan gambar, teks, audio, video, dan, animasi untuk visualisasi konsep sistem dalam sebuah cerita dapat memudahkan user memahami kebutuhan [9]. Teknik ini dapat menghasilkan lebih banyak kebutuhan karena interaksi dilakukan melalui media cerita yang merupakan teknik alamiah komunikasi manusia [14][16]. 
Penggunaan cerita visual sebagai media penggalian kebutuhan pada teknik ini mengharuskan adanya keahlian khusus pada tim pengembang. Keahlian menerjemahkan kebutuhan dalam bentuk cerita visual sangat dibutuhkan. Selain itu, tidak mudah membuat gambar yang dapat bercerita.

\subsubsection{Use Case}

Teknik elisitasi berdasarkan skenario yang menjelaskan interaksi antara aktor dengan sistem yang akan dibangun. Teknik ini berupa diagram fungsionalitas dari suatu sistem, sehingga pengguna sistem paham dan mengerti mengenai kegunaan sistem yang akan dibangun [9]. Penggunaan teknis ini lebih mudah dipahami dan merepresentasikan bahasa user [25]. Selain itu, penggunaan test case dan exception flow pada use case dapat membantu proses validasi kebutuhan [16]. Terkait dengan karakteristik proyek, use case cocok untuk proyek yang memiliki banyak kebutuhan fungsional dan banyak aktor yang terlibat dalam sistem.

Use case cocok untuk mendefinisikan kebutuhan fungsional, namun tidak untuk menentukan kebutuhan nonfungsional. Adanya banyak template justru terkadang membingungkan. Selain itu teknis ini kurang sesuai untuk extreme programming karena sangat mementingkan dokumen.

\subsubsection{Role Playing}

Teknik ini memberi kesempatan kepada stakeholder untuk bisa mengalami experience yamg sama dari sudut pandang user sebagai pengguna. Role Playing menggunakan skenario yang di set oleh tim developer, dengan dialog yang spontan. Cocok digunakan untuk situasi dimana kebutuhan yang akan dihasilkan membutuhkan perspektif berbeda dari user yang bermacam-macam. Dari sisi developer, tim dapat lebih memahami produk yang sebenarnya dari perspektif user. Teknik ini tidak kaku dalam memilih stakeholder yang harus memainkan peran. Ketika key stakeholder tidak dapat diakses, maka dapat digantikan oleh wakilnya [11].

Penggunaan skenario sebagai media dalam bermain peran, mengharuskan developer mengidentifikasi peran yang akan ditampilkan dalam skenario. Kemungkinan kesalahan dalam identifikasi peran dapat menghasilkan skenario yang tidak tepat. Dialog spontan yang digunakan menjadi hambatan dalam bermain peran dan dimungkinkan hasil kebutuhan yang kurang mendalam.

\subsubsection{Prototyping}

Teknik ini merupakan versi awal dari sistem perangkat lunak yang digunakan untuk mendemonstrasikan konsep, mencoba pilihan rancangan, dan secara umum mencari lebih jauh tentang kesalahan dan solusi yang dimungkinkan. Cocok digunakan untuk sistem dengan kondisi kebutuhan yang belum pasti [13]. Bagusnya teknik ini adalah menyediakan model konkret yang mungkin akan diserahkan pada akhir proyek dengan kebutuhan yang lebih nyata melalui contoh yang sederhana [11][14]. Kesenjangan antara analis dan user selama proses elisitasi dapat dihubungkan dengan teknik ini [26]. Adanya identifikasi kesalahan di awal, maka waktu dan biaya pengembangan sistem dapat dikurangi [13]. Adanya banyak jenis prototype dapat membingungkan bagi user dalam mengikuti berbagai macam sesi [25].

Akan tetapi, untuk pengembangan sistem yang benar-benar baru tidak cocok menggunakan teknik ini untuk penggalian kebutuhan. Hal ini dikarenakan rancangan sistem yang dihasilkan ini berasal dari kebutuhan yang sudah teridentifikasi dari sistem sejenis yang sebelumnya dibangun [8]. Teknik ini kurang ada analisa dokumen secara lengkap [13]. 


\subsubsection{Analisa Dokumen}

Teknik pengumpulan kebutuhan dengan cara menganalisa dokumen yang terkait dengan domain permasalahan dalam organisasi. Pengumpulan informasi dari analisa dokumen dapat mengetahui secara langsung terkait sistem yang telah ada untuk membangun sistem yang baru [13]. Teknik ini dapat membantu mempersiapkan bahan pertanyaan untuk interview [17]. Analisa dokumen terkadang sulit dilakukan dan dibutuhkan waktu yang lama untuk memahami maksud dokumen [14]. Tidak hanya itu, karena dokumen merupakan benda mati tidak bisa diajak berinteraksi, maka dimungkinkan adanya kesalahpamaham mengartikan isi dokumen [14].

\subsubsection{Perkembangan Teknik Elisitasi}

Berdasarkan review paper diketahui bahwa terdapat 3 teknik elisitasi yang mengalami perkembangan, yakni: interview, brainstorming, dan analisa dokumen.

\section{1) Interview}

Teknik interview mengalami perkembangan pada tahun 2004 [27], 2012 [28], dan 2016 [29]. Pada tahun 2004 [27], penggalian kebutuhan menggunakan teknik interview berkembang menggunakan indepth interview atau dikenal dengan istilah laddering. Informasi hasil interview yang direkam dalam tape akan diinputkan secara langsung ke sebuah software tool ladder yang akan dihasilkan linked chain berdasarkan jawaban narasumber. Melalui perkembangan ini, hasil interview bukan hanya data mentah namun sudah berupa kumpulan kata kunci, yang pada penelitian ini disebut dengan Critical Success Chain.

Selanjutnya, pada tahun 2012 [28] dikembangkanlah metode baru teknik elisitasi untuk proyek skala besar. Metode ini merupakan bentuk pembaharuan teknik interview menggunakan social network analysis dan collaborative filtering. Social network analysis digunakan untuk memahami hubungan antar stakeholder yang dibentukkan dalam node (stakeholder) dan link (recommendations). Pemahaman ini selanjutnya digunakan untuk memprioriaskan stakeholder berdasarkan tingkat pengaruhnya terhadap proyek. Selanjutnya, menggunakan collaborative filtering untuk memprioritaskan requirement yang diusulkan masing-masing stakeholder berdasarkan pengaruhnya pada proyek. Pada proyek skala besar, prioritisasi stakeholder dan kebutuhan menggunakan bantuan tools karena banyaknya jumlah partisipan yang terlibat.

Perkembangan terbaru diusulkan pada tahun 2016 oleh Nauman Ahmad et. al. [29]. Adanya kenyataan bahwa tidak semua stakeholder memiliki ketersediaan waktu bertemu langsung untuk menjadi narasumber menggunakan teknik interview, maka diusulkanlah penggunaan electronic communication. Media elektronik yang digunakan adalah podcast, email, dan chatting. Hasil verifikasi menunjukkan bahwa penggunaan media elektronik (podcast, email, dan chatting) berdampak pada peningkatan kinerja proses interview. Podcast terverifikasi memberikan pengaruh yang positif sebagai sebuah oneway asynchronous communication (mendengarkan) yang efektif digunakan untuk stakeholder yang unable, enggan, dan memiliki batasan waktu untuk menggunakan email atau chatting. Email terverifikasi sebagai sebuah twoway asynchronous communication (membaca dan membalas) yang efektif digunakan untuk menginterview stakeholder yang tidak memiliki waktu bertemu secara online dengan komunikasi yang realtime. Sementara itu chatting adalah twoway asynchronous communication yang efektif untuk stakeholder yang memiliki waktu komunikasi secara real time.

\section{2) Brainstorming}

Berdasarkan hasil review paper, diketahui bahwa teknik brainstorming mengalami perkembangan pada tahun 2010 [30] dan 2015 [23]. Proses pelaksanaan yang biasanya dilakukan secara manual dalam satu 
ruangan menggunakan kertas, papan, atau pun spidol berkembang menggunakan fasilitas web applicationtools dan Social Network Site (SNS).

Pada tahun 2010 [30], dikembangkan metode spatial Hypertext Wiki untuk mendukung proses penggalian kebutuhan. Menggunakan tools web application, wiki memberikan keuntungan dalam proses elisitasi kebutuhan karena mendukung terjadinya kolaborasi terbuka pada stakeholder dengan rintangan yang minim. Perubahan informasi dan ide selama proses brainstorming terlacak dengan baik karena adanya versioning. Distribusi dan kolaborasi ide juga dapat dilakukan dengan mudah dengan media ini. Dapat dilakukan manipulasi terhadap kebutuhan, dapat mengelompokkan, menghubungkan dan menggabungkan kebutuhan secara virtual. Proses negosiasi dan prioritisasi kebutuhan dilakukan menggunakan papan virtual. Lingkungan virtual ini membantu stakeholder dalam memunculkan ide.

Sedangkan pada tahun 2015 [23], digunakan SNS berupa Facebook untuk proses brainstorming. Selain faktor biaya yang cukup murah, penggunaan media Facebook juga meminimalkan usaha untuk menjelaskan bagaimana proses brainstorming dilakukan. Hal ini dikarenakan sebagian besar orang sudah mengenal Facebook. Persahabatan dan ketertarikan yang diciptakan Facebook membuat partisipasi keterlibatan user menjadi lebih tinggi. Selain itu, kendala geografis yang menjadi isu jika brainstorming dilakukan secara manual dapat diatasi dengan media Facebook. Kemampuan moderator dan motivasi menjadi isu penting pada bagian ini.

\section{3) Analisa Dokumen}

Secara umum, penggalian kebutuhan dengan teknik analisa dokumen memanfaatkan dokumen pengembangan sistem yang sebelumnya menjadi bahan review. Akan tetapi pada tahun 2012 [31] dan 2013 [32] terjadi perkembangan pada teknik ini. Dokumen model proses bisnis dipakai sebagai bahan untuk menggali kebutuhan sistem yang akan dikembangkan.

Pada tahun 2012 [31] dikembangkan teknik Requirements Elicitation oriented by business process MOdeling (REMO) yang menggali kebutuhan perangkat lunak berdasarkan pada model proses bisnis. Diagram proses bisnis yang dianalisa adalah Business Process Model and Notation (BPMN). Berdasarkan hasil studi empiris menunjukkan bahwa REMO memiliki kinerja yang lebih baik dari teknik tradisional dilihat dari indikator kecukupan, dimana teknik ini membantu menguraikan kebutuhan dari diagram proses bisnis dan mengurangi jumlah dari kebutuhan yang tidak cukup. Selain itu, pendefinisikan kebutuhan berdasar diagram proses bisnis berarti akan membantu menghasilkan sistem yang sesuai dengan proses bisnis yang ada.

Setahun kemudian, teknik Analisa dokumen berkembang lagi. Jika sebelumnya hanya menggunakan model proses bisnis sebagai dasar penggalian kebutuhan maka pada tahun 2013 [32] digunakanlah model organisasi. Model organisasi Enterprise Knowledge Development (EKD) yang digunakan sebagai acuan dalam menentukan kebutuhan terdiri dari beberapa sub model yaitu goal, business rule, concepts, business process, actors and resources, requirements and technical components. Perluasan penggunaan model ini membuat Analisa yang dilakukan lebih menyeluruh. Pendefinisikan kebutuhan akan melihat organisasi dari rencana strategis yang diterjemahkan dalam tujuan, aturan bisnis, hingga sumber daya (SDM dan material) organisasi.

\subsubsection{Kombinasi Teknik Elisitasi}

Hasil review paper juga menunjukkan dibutuhkannya kombinasi yang dilakukan pada beberapa teknik elisitasi untuk menghasilkan requirement yang tepat dan dengan jumlah yang lebih banyak. Sehingga proses elisitasi dapat berjalan lebih efektif dan efisien. Terdapat empat macam kombinasi yang diulas oleh empat paper yang telah direview seperti yang ditunjukkan pada Tabel 2. 
Paper yang diteliti oleh Mishra [19] menerapkan kombinasi tiga jenis teknik elisitasi yaitu interview, workshop dan brainstorming. Interview dilakukan kepada customer yang berpotensi terhadap pengembangan software dan workshop dilakukan untuk semua stakeholder. Kedua teknik ini dilakukan untuk menggali informasi dan menginisiasi requirement. Selanjutnya daftar requirement yang dihasilkan akan dijadikan bahan dalam teknik brainstorming untuk dianalisis.

Tabel 1 Kombinasi teknik elisitasi

\begin{tabular}{lr}
\hline \multicolumn{1}{c}{ Judul Paper } & Kombinasi Teknik Elisitasi \\
\hline $\begin{array}{l}\text { Successful requirement elicitation by combining requirement engineering } \\
\text { techniques [19] }\end{array}$ & Interview, workshop dan brainstorming \\
$\begin{array}{l}\text { A situational method engineering approach to requirements elicitation } \\
\text { workshops in the software development process [22] }\end{array}$ & Kuesioner, brainstorming, dan analisa dokumen \\
$\begin{array}{l}\text { The front end of innovarion - a group method for the elicitation of software } \\
\text { requirements [17] }\end{array}$ & Interview, brainstorming dan analisa dokumen \\
\begin{tabular}{l} 
Requirement Elicitation Using a Combination of Prototypes and Scenario [25] \\
\hline
\end{tabular} & Use case, Prototyping \\
\hline
\end{tabular}

Kombinasi yang lainnya juga dilakukan oleh Coulin [22], pada penelitiannya dikombinasikan teknik kuesioner, brainstorming dan analisa dokumen. Pertama dilakukan analisa dokumen pada fase penentuan ruang lingkup dan mengumpulkan informasi dasar sebagai bekal dalam pengumpulan requirement. Selanjutnya brainstorming dilakukan untuk mengidentifikasi proses kerja bisnis, fitur, dan kemampuan sistem yang akan dibuat sehingga dihasilkan tujuan dari dibuatnya sistem.

Interview, brainstorming dan analisa dokumen dikombinasikan oleh Hannola [17]. Pada tahap persiapan requirement elicitation dilakukan analisa terhadap dokumen organisasi untuk mendefinisikan tujuan dan jadwal dikembangkannya sistem. Selanjutnya dilakukan unstructured interview untuk menyusun proses elisitasi dan alat-alat yang akan digunakan. Kemudian brainstorming dilakukan untuk menghasilkan daftar requirement yang tepat dan dibutuhkan dalam pengembangan sistem.

Paper lain yang melakukan kombinasi teknik elisitasi adalah paper yang berjudul Requirement Elicitation Using a Combination of Prototypes and Scenario [25]. Kombinasi yang dilakukan dalam paper ini adalah antara use case scenario dan prototyping. Hasil dari use case analisis digunakan untuk merancang prototyping.

Berdasarkan empat kombinasi yang ada, dapat disimpulkan bahwa interview, brainstorming, dan analisa dokumen adalah komposisi kombinasi teknik elisitasi yang paling sering digunakan. Analisa dokumen digunakan pada fase penentuan ruang lingkup dan mengumpulkan informasi dasar sebagai bekal dalam pembuatan daftar pertanyaan untuk interview secara personal. Selanjutnya brainstorming dilakukan setelah terkumpul informasi dasar kebutuhan dari stakeholder. Hasilnya berupa daftar kebutuhan sistem yang akan dibangun.

Mengingat setiap teknik memiliki kelebihan dan kekurangan, maka sangat dimungkinkan untuk dilakukan kombinasi dalam penggunaannya. Teknik terbaik adalah ketika teknik tersbut digunakan pada kondisi yang tepat. Oleh karenanya, guna menghasilkan daftar kebutuhan yang akurat dapat dipilih teknik yang sesuai kondisi pengembangan perangkat lunak. Apabila satu teknik dirasa tidak cukup, maka kombinasi adalah solusi yang terbaik. 


\section{Kesimpulan}

Pada bagian ini berisi tentang poin-poin utama yang dihasilkan dari penelitian yaitu berupa kesimpulan. Selain itu juga diberikan rekomendasi dan saran untuk penelitian selanjutnya sehingga ilmu tentang elisitasi kebutuhan perangkat lunak dapat lebih berkembang serta memudahkan dalam praktiknya.

\subsection{Simpulan}

Berdasarkan hasil penelitian dan uraian pembahasan tentang teknik-teknik elisitasi maka dapat dihasilkan beberapa kesimpulan sebagai berikut.

1) Interview merupakan teknik elisitasi yang paling banyak diteliti (sebanyak 17 paper dalam 9 tahun)

2) Interview, brainstorming, dan analisa dokumen adalah teknik yang mengalami perkembangan, dengan perkembangan terbanyak pada teknik interview (tahun 2004, 2012, dan 2016).

3) Interview, brainstorming, dan analisa dokumen merupakan komposisi kombinasi teknik elisitasi yang sering digunakan.

\subsection{Saran}

Penelitian yang dilakukan pada karya tulis ini masih memiliki keterbatasan dan kekurangan sehingga masih perlu dilakukan penelitian lanjutan dari penelitian ini. Teknik elisitasi pada proses penggalian kebutuhan telah banyak dikembangkan, namun penggunaannya tidak merata. Hanya beberapa teknik elisitasi saja yang seringkali digunakan karena mudah untuk diterapkan meskipun belum tentu penggunaannya sesuai dengan kondisi pengembangan perangkat lunak yang akan dijalankan. Oleh karena itu pada penelitian selanjutnya perlu dibuat peta penggunaan teknik elisitasi terhadap jenis proyek pengembangan perangkat lunak berdasarkan karakteristiknya sehingga dapat dihasilkan requirement yang tepat dan berkualitas. Selain itu, pada penelitian selanjutnya juga perlu dilakukan analisis dengan menggunakan unit analisis lain seperti cross tabulasi atau analisis statististik yang lainnya agar cakupan hasil analisis menjadi lebih luas.

\section{Daftar Rujukan}

[1] T. E. Bell and T. A. Thayer, "Software requirements: Are they really a problem?," in Proceedings of the 2nd international conference on Software engineering, 1976, pp. 61-68.

[2] Z. M. Kasirun, "A survey on the requirements elicitation practices among courseware developers," Malays. J. Comput. Sci., vol. 18, no. 1, pp. 70-77, 2005.

[3] R. O. Briggs and P. Gruenbacher, "EasyWinWin: Managing Complexity in Requirements Negotiation with GSS," Th Hawaii Int. Conf. Syst. Sci., p. 10, 2002.

[4] A. Eberlein, “Agile Requirements Definition: A View from Requirements Engineering," p. 5.

[5] A. van Lamsweerde, "Requirements engineering in the year 00: a research perspective," in Proceedings of the 2000 International Conference on Software Engineering. ICSE 2000 the New Millennium, Limerick, Ireland, 2000, pp. 5-19.

[6] B. Boehm and R. Turner, "Balancing agility and discipline: evaluating and integrating agile and plan-driven methods," in Proceedings. 26th International Conference on Software Engineering, Edinburgh, UK, 2004, pp. 718-719.

[7] K. Moløkken and M. Jørgensen, "A Review of Surveys on Software Effort Estimation,” Int. Symp. Empir. Softw. Eng., p. 8, 2003.

[8] A. Davis, O. Dieste, A. Hickey, N. Juristo, and A. M. Moreno, "Effectiveness of requirements elicitation techniques: Empirical results derived from a systematic review," in 14th IEEE International Requirements Engineering Conference (RE'06), 2006, pp. $179-188$.

[9] S. Tiwari, S. S. Rathore, and A. Gupta, "Selecting requirement elicitation techniques for software projects," in Software Engineering (CONSEG), 2012 CSI Sixth International Conference on, 2012, pp. 1-10.

[10]D. Carrizo, O. Dieste, and N. Juristo, "Systematizing requirements elicitation technique selection," Inf. Softw. Technol., vol. 56, no. 6, pp. 644-669, Jun. 2014.

[11]A. M. Hickey and A. M. Davis, "Elicitation technique selection: how do experts do it?," in Requirements engineering conference, 2003. proceedings. 11th ieee international, 2003, pp. 169-178. 
[12]N. Boulila, A. Hoffmann, and A. Herrmann, "Using Storytelling to record requirements: Elements for an effective requirements elicitation approach," in 2011 Fourth International Workshop on Multimedia and Enjoyable Requirements Engineering (MERE'11), 2011, pp. 9-16.

[13] S. Khan\$1 \$, A. B. Dulloo, and M. Verma, Systematic review of requirement elicitation techniques. India, 2014.

[14]A. Umber, M. S. Naweed, T. Bashir, and I. S. Bajwa, "Requirements Elicitation Methods," Adv. Mater. Res., vol. 433-440, pp. 6000-6006, Jan. 2012.

[15]T. ur Rehman, M. N. A. Khan, and N. Riaz, "Analysis of Requirement Engineering Processes, Tools/Techniques and Methodologies," Int. J. Inf. Technol. Comput. Sci., vol. 5, no. 3, pp. 40-48, Feb. 2013.

[16] N. Garg, P. Agarwal, and S. Khan, "Recent advancements in requirement elicitation and prioritization techniques," in Computer Engineering and Applications (ICACEA), 2015 International Conference on Advances in, 2015, pp. 237-240.

[17]L. Hannola, U. Nikula, K. Leino, M. Tuominen, and H. Kalviainen, "The front end of innovation-a group method for the elicitation of software requirements," Int. J. Innov. Learn., vol. 7, no. 3, pp. 359-375, 2010.

[18]Z. Zhang, "Effective requirements development-A comparison of requirements elicitation techniques," Softw. Qual. Manag. XV Softw. Qual. Knowl. Soc. E Berki J Nummenmaa Sunley M Ross G Staples Ed Br. Comput. Soc., pp. 225-240, 2007.

[19]D. Mishra, A. Mishra, and A. Yazici, "Successful requirement elicitation by combining requirement engineering techniques," in Applications of Digital Information and Web Technologies, 2008. ICADIWT 2008. First International Conference on the, 2008, pp. 258-263.

[20] O. I. Al Mrayat, N. Norwawi, and N. Basir, "Requirements Elicitation Techniques: Comparative Study," Int. J. Recent Dev. Eng. Technol., vol. 1, no. 3, pp. 1-10, 2013.

[21]A. Sutcliffe and P. Sawyer, "Requirements elicitation: Towards the unknown unknowns," in 2013 21st IEEE International Requirements Engineering Conference (RE), 2013, pp. 92-104.

[22]C. Coulin, D. Zowghi, and A.-E.-K. Sahraoui, "A situational method engineering approach to requirements elicitation workshops in the software development process," Softw. Process Improv. Pract., vol. 11, no. 5, pp. 451-464, Sep. 2006.

[23]N. Seyff, I. Todoran, K. Caluser, L. Singer, and M. Glinz, "Using popular social network sites to support requirements elicitation, prioritization and negotiation," J. Internet Serv. Appl., vol. 6, no. 1, Dec. 2015.

[24] S. Hassan, U. Qamar, and M. A. Idris, "Purification of requirement engineering model for rapid application development," in Software Engineering and Service Science (ICSESS), 2015 6th IEEE International Conference on, 2015, pp. 357-362.

[25]M. Mannio and U. Nikula, Requirements elicitation using a combination of prototypes and scenarios. Lappeenranta: Lappeenranta University of Technology, 2001.

[26] M. Joseph, "Collaborative Requirements Elicitation Using Elicitation Tool for Small Projects."

[27]T. Tuunanen and M. Rossi, "Engineering a method for wide audience requirements elicitation and integrating it to software development," in System Sciences, 2004. Proceedings of the 37th Annual Hawaii International Conference on, 2004, pp. 10-pp.

[28] Soo Ling Lim and A. Finkelstein, "StakeRare: Using Social Networks and Collaborative Filtering for Large-Scale Requirements Elicitation," IEEE Trans. Softw. Eng., vol. 38, no. 3, pp. 707-735, May 2012.

[29] N. Ahmad, I. Dweib, and J. Lu, "Effects of Electronic Communications on Interview Techniques in Requirements Engineering," Egypt. Comput. Sci. J., vol. 40, no. 1, 2016.

[30]C. Solis and N. Ali, "Distributed Requirements Elicitation Using a Spatial Hypertext Wiki," 2010, pp. 237-246.

[31] S. R. C. Vieira, D. Viana, R. do Nascimento, and T. Conte, "Using Empirical Studies to Evaluate the REMO Requirement Elicitation Technique.," in SEKE, 2012, pp. 33-38.

[32][32] M. de Oliveira, D. Viana, T. Conte, S. Vieira, and S. Marczak, "Evaluating the REMO-EKD technique: A technique for the elicitation of software requirements based on EKD organizational models," in 2013 3rd International Workshop on Empirical Requirements Engineering (EmpiRE), 2013, pp. 9-16. 
Endang Sulistiyani dan Sasmi Hidayatul Yulianing Tyas / Jurnal SISFO Vol.08 No.03 (2019) 141-158

Halaman ini sengaja dikosongkan 
